\title{
History and Social Progress
}

Reflections on Mead's Approach to History

Daniel R. Huebner

\section{(2) OpenEdition \\ Journals}

Electronic version

URL: http://journals.openedition.org/ejpap/637

DOI: 10.4000/ejpap.637

ISSN: 2036-4091

Publisher

Associazione Pragma

\section{Electronic reference}

Daniel R. Huebner, « History and Social Progress », European Journal of Pragmatism and American Philosophy [Online], VIII-2 | 2016, Online since 16 January 2017, connection on 30 April 2019. URL http://journals.openedition.org/ejpap/637 ; DOI : 10.4000/ejpap.637

This text was automatically generated on 30 April 2019

\section{(c) $($ ) $\odot$ (8)}

Author retains copyright and grants the European Journal of Pragmatism and American Philosophy right of first publication with the work simultaneously licensed under a Creative Commons AttributionNonCommercial-NoDerivatives 4.0 International License. 


\title{
History and Social Progress
}

\author{
Reflections on Mead's Approach to History
}

\author{
Daniel R. Huebner
}

\section{AUTHOR'S NOTE}

Portions of this paper were first presented at a conference on "Pragmatism and Sociology" at the University of Chicago, August 2015. I wish to thank the organizers and participants of that conference for fruitful discussions that have benefited the present paper.

1 George Herbert Mead is familiar to many sociologists and social psychologists for his theory of the social genesis and development of the self, but he almost never features in discussions of history or the philosophy of history. Yet Mead took the problems of conceptualizing and studying history seriously and consistently wrote with problems of history in mind. In this paper, I seek to demonstrate not only that George Mead wrote substantively on historical issues, but also that his long-ignored conceptualization has wide-reaching implications for how we study history. The key lies in identifying the connections between his understanding of the nature of the past and how to understand it, on the one hand, and his broader social philosophy, on the other. The paper is not intended as a comprehensive restatement of Mead's work on history, but is rather an attempt to explore some of the possibilities that Mead's approach opens in light of the other aspects of Mead's philosophy and in response to possible criticisms. I hope to show that the implications of Mead's approach warrant greater scrutiny, not just from those interested in Mead or classical American pragmatism, but from researchers in any disciplines that employ historical research, because Mead's work explores the nature of the relationship between history and social progress.

The paper begins with a discussion of the major sources for Mead's understanding of history and temporality and a review of literature that has interpreted and built upon Mead's work on history, which I hope will be useful to scholars who find Mead's approach worth pursuing. Special emphasis is placed on the productivity of social scientific 
interpretations of Mead's philosophy as a unique theory of action and on the recent renewed focus on Mead's approach to history. This review provides an overview of the major features of Mead's approach as they have typically been understood and provides orientation for the proposals made in later sections.

Following this review, I consider potential criticisms or shortcomings of Mead's approach - as overly presentist or historicist - and show how recourse to other aspects of Mead's philosophy may address such criticisms. In particular, I draw upon his dynamic and semiotic theory of social action, his view of the relationship between democratic social practices and forms of knowledge, and his theory of social self-consciousness. Such an examination opens suggestive avenues for philosophers of history and for historians that demonstrate the novel impact Mead's approach may have on historical investigations. In considering criticisms of Mead's presentist focus - that the past is always discovered in the present - I show that Mead provides a novel grounding of our understanding of history in ongoing social processes, and in considering criticisms of Mead's historicism that knowledge, while claiming to be universal, is always a product of its time - I propose that Mead's approach seeks to develop better historical knowledge through more participatory, democratically inclusive social practice. The paper concludes by seeking to synthesize Mead's social and dynamic approach to historical inquiry around the notion of "responsibility" by proposing that, in Mead's view, historians have a profound responsibility to social reconstruction and progress.

\section{Reconstructing and Interpreting Mead on History}

2 Mead's major philosophical discussions of history and the nature of temporality may be found partly in a variety of works published during his lifetime (esp. Mead 1930, 1929a, 1929c, 1908, 1899; and Rigney \& Lundy 2015), and partly in posthumously published works constructed from students' and stenographers' notes and Mead's manuscripts (esp. Mead 1938 , 1936, 1932). Perhaps because of the near monopoly of the posthumously published Mind, Self, and Society (Mead 2015) in most discussions of Mead's philosophy, the remarkable breadth and depth of Mead's reflections on history in works such as The Philosophy of the Present (1932), Movements of Thought in the Nineteenth Century (1936), and "The Nature of the Past" (1929a) have largely remained in obscurity (Huebner 2014: 191; and Camic 2016). Along with these major sources, remarks about historical events or about the nature of history appear throughout Mead's other published works, sometimes in surprising contexts, and seem to indicate the ubiquitous importance Mead placed on such problems of history in his philosophy. The dozens of extant student notes from his courses that remain unpublished (see Huebner 2014 for complete listing) rarely fail to discuss historical transformations in social consciousness. Indeed, Mead's first academic position was as an instructor at the University of Michigan teaching courses in the history of philosophy alongside courses in physiological psychology, and he continued to teaching and write on historical topics his entire career.

3 A major problem confronting those who would seek to reconstruct Mead's theory of history across his entire oeuvre is that much of the relevant material is not found in selfcontained, tightly-argued published articles, but rather in disparate remarks as recorded by students or in manuscript fragments of variable incompleteness. This fact likely indicates that Mead repeatedly returned to these problems of history throughout his career and was perhaps even repeatedly unsatisfied with their solution. This should 
probably caution us against a strictly held literalism and finality with regard to Mead's theory. I suggest throughout the following paper that the most productive course may be to focus on the kinds of approaches Mead's broader philosophy offers as the starting point for our own inquiry rather than attempting to find the final answer on historical topics.

4 Although Mead's work on the nature of history has never been a central aspect of the literature commenting on his philosophy, there have been disparate analyses of his work on history and temporality that may be found in the social sciences and social theory (Bergmann 1981; Bourgeois \& Rosenthal 1990; Bourgeois \& Rosenthal 1993; Flaherty \& Fine 2001; Frings 1983; Joas 1985: Ch. 8; Maines, Sugrue, \& Katovich 1983; Moore 1936; Nowotny 1992; Strauss 1991; and Tillman 1970), and in the literatures on metaphysics, the philosophy of science, and the history of philosophy (Brogaard 1999; Cook 1979; Eames 1973; Fen 1951; Leahy 1953; Lee 1963; Miller 1943, 1973: Ch. 11; Murphy 1932; Natanson 1953; Stone 2013; Tonness 1933; and Ushenko 1934). Despite the diversity of these literatures, a few core themes that are important to subsequent discussions in this paper may be identified: (1) nature, itself, is temporal; (2) human consciousness emerges through temporal social processes; (3) and science emerges in history as the most reflective form of human consciousness. First, natural reality must be understood as profoundly processual and temporal rather than static. Mead was in dialogue with philosophers of science, physicists, mathematicians, and others in attempting to formulate an understanding of reality that was necessarily relational and perspectival, and in which those elements of reality did not always already exist, but rather continually emerged. He was strongly influenced early in his career by evolutionary theories and later in his career by work in relativity theory and by the process philosophies of Alfred North Whitehead and Henri Bergson. Second and concomitantly, Mead argued that human social transformations are intrinsic to how we understand natural reality. Much of his work is directed toward examining how the cognizing subject - the "self" - only emerges through the course of historical social processes, and that it is therefore not independent of history. In Mead's view, one of the forms of self-reflection in which humans engage is seeking to understand historical events. The development of such selfreflective capacities happens in both phylogenetic (the development of human species characteristics) and ontogenetic (the development of the individual's self consciousness) timeframes. Third, scientific inquiry - understood by Mead (1917a) as the social process of working to incorporate new experiences of observers into a continually reformulated universalizing perspective - emerges as the most self-reflective form of social consciousness in the modern era, and an inherent part of this process is inquiry into historical events. It may be noted that in Mead's work, and consequently in the interpretations made of that work, there is little effort to maintain a principled line of demarcation between the history of philosophy and the philosophy of history - that is, between Mead's understanding of the historical movements of scientific and philosophical thought, on the one hand, and his theory of the role of history in human social action, on the other hand. As the analysis below seeks to demonstrate, the way thought unfolds in history is inseparable, in Mead's view, from the way we understand historical development, itself - and both must be understood in terms of social transformations, not the self-unfolding of ideas.

5 Although few scholars in the field of history proper have seriously engaged with Mead's ideas on history and temporality, there are a number of works in the historically-oriented 
social sciences that have sought to interpret and apply Mead's ideas and for whom "pragmatism" means primarily the work of Mead and John Dewey. While I do not intend to comprehensively review that literature here, it is worth pointing out that there are some general points consistently attributed to Mead and other pragmatists in such historical-sociological work. The pragmatists are considered proponents of a nonteleological view of history in which emphasis is placed on: the formation and sequence of events as problematic situations in the course of human social processes (Abbott 2001; Schneiderhan 2011; and Wagner-Pacifici 2010); the importance of habits, cultural conventions, and institutions in shaping the course of history (Ansell 2011; Baldwin 1988; Gross 2010, 2009); the self-reflective abilities of human actors to respond creatively, open new possibilities of social action, and create through social action the very values toward which action is directed (Baert 2005; and Joas 1996); the experiential ordering of temporal events by means of narrative and symbols (Maines 1993; and Maines et al. 1983); and hence an overall view of society as a historically dynamic process of people "doing things together" (Becker 1976; and Blumer 1969). They are affinities between this view and recent forms of cultural or practical institutionalism in historical social science (e.g., Adams, Clemens, \& Orloff 1995), and connections between pragmatism and the "new institutionalist" analysis associated with organizational studies (Powell \& DiMaggio 1991) have also been noted (e.g., Scott 1995).

6 The common view implicit in such social scientific approaches is that the core of pragmatism is its unique theory of action. ${ }^{1}$ To my mind, the most convincing work to explain this characterization is found in the work of Hans Joas $(1996,1985)$, who argues that Mead's theory of action centers the corporeal or embodied nature of human action, the necessarily situational or contextual nature of intentionality, and the essentially social nature of action, both onto- and phylo-genetically (see also Gross 2010 and Margolis 1986 for related discussions). Put another way, action is ultimately a process of human bodies oriented to common practical problems that develop in the course of life together. Human mind or thought (in all its connotations), thus, develops within this process through communication that is bodily or gestural, social or intersubjective, and situational or oriented to solving problems of real life. It is only the insistence of all of these features that truly sets Mead's pragmatism apart as a starting point for historical inquiry, because such a theory offers a comprehensive conceptualization of action that overcomes the problems of "residual categories," a challenge raised but not adequately solved by Talcott Parsons (1937). By developing a theory that leaves no residual categories - such as non-rational or non-normative action (Joas 1996: 4-5) - unexplained, Mead provides an approach to human action applicable to events of all times and places not just those that are judged to be oriented toward appropriately rational ends or norms - as well as individuals' subjective understandings of their own actions.

7 It might also be noted parenthetically that framing a philosophy in terms of human action already implies history. On the one hand, a comprehensive theory of human action must be able to conceptualize action not directly witnessed, including past actions - an approach that I have elsewhere proposed is key to understanding the development of certain concepts of social theory, such as Max Weber's ideal types and W. I. Thomas's situational analysis (Huebner 2014: 13-5). And on the other hand, as R. G. Collingwood (1999: 40; 1956: 9) famously noted, "historians think and always have thought that history is about res gestae, deeds, human actions done in the past." A comprehensive theory of action must be adequate to the explanation of history, and history is ultimately the study 
of action. ${ }^{2}$ The further implications that can be derived from applying a pragmatist theory of action to the problems of history are explored in subsequent sections of this paper.

8 In the last few years, Mead's understanding of history and temporality has also been the subject of renewed attention as part of a broader reevaluation of Mead's philosophy (Camic 2016; Campbell 2013; Côté 2013, 2015; Garcia Ruiz 2013; Joas 2016, 2013; Rigney \& Lundy 2015; Stone 2013; Thomas 2016; and Westbrook 2016). My own contribution to this recent literature, upon which the present paper builds, has sought to demonstrate that Mead consistently taught courses in the history of science and philosophy throughout his career, that he wrote several major articles and participated in professional discussions regarding the history of science, that among the Deweyan pragmatists Mead was considered the definitive expert on the history of thought, and that Mead supported efforts to institutionalize the history of science as a field of inquiry (Huebner 2016). In general, I have sought to develop an analysis of Mead's pragmatism both as a topic for historical reconstruction and as a subtle perspective from which to engage in social scientific study of knowledge - that is, to treat Mead as part-subject matter and partmethod (Huebner 2014). Hans Joas and I have also collaborated on projects to bring to light new interpretations of Mead and his work (Joas \& Huebner 2016; and Mead 2015).

As a result of this renewed literature, it is not unreasonable to conclude that Mead was the classical American pragmatist who worked most consistently and substantively on the problems of history. Throughout these various efforts, Mead appears to have consistently argued that the history of thought depends on practical social changes and that what counts as history is, itself, the result of changing ways in which the social order becomes problematic in social consciousness. These findings echo some of the earliest conclusions of Mead's students and colleagues, that his method in approaching historical investigations was to identify the socio-historical context in which intellectual or philosophical problems arise and to show how thinkers of the time handled these problems in context (Castell 1937; and Moore 1936). All of these leads in Mead's work and in the various interpretations that have been made of them are very suggestive and may prove useful to historical investigators. In addition, however, I wish to propose that Mead sketched a profoundly social and dynamic orientation to historical explanation, the implications of which have not been fully recognized, and proposed an approach that may ground the possibility for progress and ethical responsibility in historical knowledge. The additional orientation that may be gained by examining the interconnections between Mead's understanding of history and the other aspects of his philosophy underscores both why Mead's approach may be viewed as a practically and ethically productive framework for research, and how his approach avoids becoming merely another flat, relational history.

\section{Presentism and History as Social Problems}

10 Mead was acutely aware of a fundamental challenge that his work faced in accounting for history, and of the criticism that he (and John Dewey) received in this regard (Joas 2016; Huebner 2016; and Joas 1993). In centering itself theoretically on action in the present, pragmatism raises the challenge of relativism, both in the sense that one's present claims about the features of history seem to be merely constructed rather than revealing of absolute truth, and that regardless of its content one's own knowledge must also be 
historically grounded, so it can apparently be no more universally true than any other knowledge. The first we might call, for sake of convenience, the problem of "presentism," and the second the problem of "historicism," although these are intimately tied to one another.

11 Mead acknowledged the problem of presentism head-on in a number of his writings. Most obviously, he explicitly claimed in his posthumously published Carus Lectures, The Philosophy of the Present, that "reality exists in a present" (Mead 1932: 1). The past can only take on significance in relation to a present, so the kind of features and events history has is continually "reconstructed" from this reality of ongoing social process. The past is both "irrevocable and revocable" in his view, with an emphasis on how the supposedly irrevocable "'real' past" is only ever encountered through the present within which discoveries emerge, so each new emergent-present makes for a "different past." Far from meaning "radical doubt" in historical fact, this means that we take the past for granted as "given" except when the problems of the present prompt us to "rewrit[e] the past to which we now look back" so as to be capable of bringing about a different "world that will be" in the future (Mead 1932: 3-5). It is easy to see how the past is "revocable," in Mead's dynamic view, but its "irrevocability" seems to refer to the "apparatus" of "documents, oral testimony, and historical remains," the "memory images and the evidences by which we build up the past" that have a duration through time so that they form the given - but not essentially permanent - background against which discoveries of new evidence of the past, or reinterpretations of those durable apparatus, occur in the present (Mead 1932: 5 , 29-30).

12 History, in Mead's view, must necessarily be an aspect of the process of society's selfknowledge, as every transformation of society that gives rise to problematic courses of action necessarily transforms what we consider history. What is needed is not a recovery of the past as it really was, but a reconstruction that enables us to "interpret what is arising in the future that belongs to the present" (Mead 1932: 30). No past that can be constructed can be "as adequate as the situation demands," because the "implications of the present" could be carried further than they ever practically are in pursuit of constructing "a past truer to the present within which the implications of this past lie" (Mead 1932: 31). Notice here that social reconstruction in the service of a better future necessitates a rewriting of history, and the construction of history is simultaneously a practical and ethical endeavor for the historian.

13 This problem of the ongoing-present remaking the past means, for Mead, that even the very way in which historians formulate questions - to what features of reality and other bodies of knowledge they turn as evidence and fact - is historically variable. Mead (1910) argued, for example, that the turn away from political history toward social and anthropological history - specifically, the "New History" of American historian James Harvey Robinson in the early twentieth century - was an indication that new "problems" had become central to society. In Mead's analysis, historians seek out new kinds of analysis and accounts when a new "social consciousness" arises that faces new questions of social function.

Mead's account, of course, raises important questions about how historians are affected by changes in the general social consciousness (or what early sociologists of knowledge following Karl Mannheim (1936) called the problem of "imputation" - how we validly connect the trends of thought or consciousness to the actions of particular social groups or individuals (e.g., Child 1941). Mead's most direct answer to this question comes from 
his work on the history of modern scientists, where the individual investigator is made the center of analysis (Mead 1917a), an analysis which builds upon his theory of the social nature of the self. Individual investigators wrestle with problems that conduct presents to them in the course of their social lives, meaning their work depends necessarily on their understanding of the problems of previous work by themselves and others, as those problems are interpreted from their own experience. The individual investigator - and in this respect the historian is no different from the experimental biologist - as socialized in "a highly organized society," finds problems with taken-for-granted assumptions or practices in his or her own experience, and instead of solving the problems through the adoption of a new "subjective attitude" about them, develops a new "object" of experience that attempts to incorporate all previous experiences.

As I have suggested elsewhere (Huebner 2016: 50,58), Mead's explication of this process of inquiry sought to demonstrate the superiority of such a pragmatist approach over socalled realist approaches. The New- and Critical Realist philosophers of the time (Holt et al. 1912; and Drake et al. 1920) misunderstood the pragmatists by proposing that the pragmatists' conception of inquiry was a subjective process: people confronted by anomalies change their minds about some aspect of reality. Mead was a particular target of realist philosophers of history Donald C. Williams (1934), A.O.Lovejoy (1939), and Maurice Mandelbaum (1948), and of essayist Elinor Castle Nef (1953: 417-8), who was Mead's niece married to historian John U. Nef (Huebner 2016: 52-3). But the alternatives posed by realistic approaches must always in some way assume an independent real reality that is unaffected by human action and yet knowable in better or worse ways by humans. Mead's solution proposes instead that the object of experience - a trace of a historical event or an observation of a natural phenomenon - is actually reconstructed into a different object by a social process of communication in which experiences with the object by particular individuals conflict with socially taken-for-granted ways of responding to the object (Mead 1917a). The experience of the socialized individual in the present is absolutely essential to the very nature of reality (in any way that it can be conceived) and hence the social process is continually necessary to the transformations of that reality. This approach to inquiry is just as essential to historical investigation and underscores Mead's broad understanding of "science" to include all the ways in which reflection on experience is capable of changing reality. ${ }^{3}$

It would be easy to see in Mead a willing surrender to presentism; after all, what can we say if even what counts as history fundamentally changes, and if even the authority of individual experience is variable across time? In order to answer this question adequately, Mead's broader theory of action is necessary. Historical investigators, Mead seems to argue, in order to develop a self-reflective enterprise, must examine the kinds of problems that confront them in the course of their action in ongoing social processes, and in reflecting on other times and places the investigator must also examine the collective problems of those times and places as they appear to have presented themselves in those times and places. When Mead examined historical events, he reportedly exemplified this theory, because his discussions did not attempt a "mere reproduction" of a historical event but rather proposed a "selective reconstruction, for present purposes and in the light of present problems" (Murphy 1936). And when Mead made specific claims about history, he consistently found them in eminently practical problems: the expansion of Ancient Greek commerce in Asia Minor was key to the development of speculative natural philosophy (Mead 1896) and the application of steam 
power to industry prompted the development of thermodynamic laws (Rigney \& Lundy 2015), for example.

This solution, because it is specifically and thoroughly social, may be more satisfactory in historical inquiry for much the same reason that Mead argued we may prefer a thoroughly social theory of mind (Mead 2015: 223): because it is better able to ground its own (and its alternatives') presuppositions. For example, an "evolutionary" (i.e., historical) theory of the state may be preferred to a "contract" theory, in Mead's view, because social-contract theories cannot explain the existence of minds and selves that they must presuppose in explaining how such already-conscious individuals enter into society. Evolutionary theories, however, which must only presuppose "the existence of the social process of behavior," are fully able to ground this seemingly self-evident presupposition in fundamental biological and physiological relations consonant with evolutionary principles (Mead 2015: 223). More broadly, the implication seems to be that the historical investigator should begin to build an argument by examining the practical, objective features of the social process - discovering which features appear to be relevant in context - and minimizing the assumption that actors of other times and places are (or are not) essentially "like us" in their cognitive faculties or motivations. This is a problem that has plagued many attempts to conceptualize historical action in terms of "rational" and "irrational" or "normative" and "non-normative" elements (see Joas 1996 for discussion).

What is clear throughout is that Mead provides a sophisticated and subtle approach to the problem of presentism - of historical inquiry always occurring in the present without simply dismissing the problem, and that Mead's approach consistently addresses this issue by rooting historical inquiry in social processes of action. We do not overcome the problem in this way, if what that means is finding a way to recover the past "as it really was," but we find an approach that conceptualizes the process of inquiry and provides a novel perspective on the investigation of historical events. Mead opens an avenue by which we may ground history as social self-reflection, and when added to additional insights developed below, may perhaps point toward better inquiry into past events.

\section{Historicism and the Grounds of Historical Knowledge}

19 Mead also addressed the criticism of "historicism" - that our understandings of the past are, themselves, located in historical contexts, and are thus no less fundamentally a product of their time. Or stated another way: because our investigations and conclusions about the past are no less fundamentally directed toward practical problems in the present, they cannot definitively claim to be faithful retellings of past events in their own terms or universally true for all future inquiries into the "same" past events. What is necessary, then, is to be able to ground the possibility of better, not just different, knowledge of history. Can we discern a criterion for progress or a logic for more encompassing knowledge in historical inquiry?

There are at least two interconnected approaches in Mead's philosophy to the problem of seeking grounds for better knowledge: (1) in terms of democratic social practices, and (2) in terms of the symbolic character of human social action. For a first approach to this question, we can look to Mead's explicit attempt to ground pragmatism historically, in a paper given on the occasion of John Dewey's seventieth birthday. For Mead, Dewey was 
the best exemplar of the principles of American pragmatism (more so than William James or Josiah Royce, whom he also considers), and he grounded the analysis of this philosophy in the "political habits" that ultimately derive from the pioneer New England settlers (Mead 1930: 212; see also Mead 1935). ${ }^{4}$ The political arrangements and consciousness of the settlers, which was centered on the "nexus of town meetings," "grew out [of] the solution of their problems" in "achieving" rather than "inheriting" a political and social union. Mead traced what he saw as implications of this basic tendency through the government, business, and educational institutions of the country. Mead noted that pragmatism has faced "opprobrium" as the "philosophy of American practicality," but it is clear that he found a ground to prefer this philosophy over those that privilege a fixed cultural ideal precisely because of its roots in democratic social practices (Mead 1930: 230-1). Cultural historian Eduard Baumgarten, in particular, found Mead's essay provocative in attempting to ground pragmatist philosophy in "town meetings" in which the participants understood themselves to be "creating the community in the process of acting together" as they confronted problematic situations (Baumgarten 1936: 83; 1938: 314). ${ }^{5}$ Baumgarten seemed to consider Mead's particular contribution to pragmatism (over Dewey's or James's) to be this grounding of a philosophy that centers social action in historical conditions of social action, themselves - a coherent, pragmatist grounding of pragmatism. So, from Mead we gain a sense that one aspect of conceptualizing the historical nature of knowledge is being able to ground one's own knowledge in the political practices from which they emerge - that is, showing how one's mode of understanding is implicated in the practices by which the political community is constituted.

21 Mead's fundamental neglect to acknowledge pervasive forms of exploitation and inequality over the course of American history - including slavery and forced labor, systematic violence against native people and dispossession of lands, social control and disenfranchisement of women, and other forms - is striking, and should of course lead us to temper the stark distinctions Mead makes between American, European, and other political contexts. This criticism can be pressed further by acknowledgement of his engagement with the American colonial settlements in Hawaii (Huebner 2014: Ch. 3), and of the various points in Mead's work in which forms of social domination are seemingly intertwined with the gaining of knowledge. But at the same time, we may wish to avoid the kind of reductionism that would explain Mead's theory (and pragmatism in general) as merely a class ideology (e.g., Herman 1944), and we should perhaps also acknowledge the attempts by Mead to advocate on behalf of "radically democratic" social reforms (Joas 1985: Ch. 2). Other major attempts to ground pragmatist philosophy in particular conditions have included the posthumously published dissertation of C. Wright Mills (1966), originally entitled "A Sociological Account of Pragmatism," which sought to ground the philosophy primarily in the context of the development and expansion of the modern independent research university in the late nineteenth century, and the work of Cornel West (1989), who emphasized the importance of American bourgeois intellectuals' experience of liberation from past constraints while also acknowledging the ways in which those experiences were nevertheless rooted in institutional apparatuses which reinforced hierarchical social distance from ordinary people. West's work, which nevertheless neglects Mead, is perhaps the most sophisticated attempt to conceptualize the relationship between the experience of freedom and agency that grounds pragmatism's sense of the importance of social reconstruction through critical intelligence, on the one hand, and the systematic inequalities that locate the possibility of 
such experiences only in particular social strata, on the other hand. The attempts at historical-sociological grounding, while extremely valuable in many respects, are necessary here only to show the profound willingness of Mead and other fellow travelers to acknowledge the particular historical conditions in which the tendencies of their own thought may be found; these works demonstrate - by its practitioners' own admission that pragmatism is not rooted in an idyllic democracy.

However, having sought to ground knowledge in historical social practices, we then need an approach that is able to differentiate forms of social practice in terms of their epistemological value. Can Mead support a claim that political contexts with more democratic tendencies (but which are not idyllic democracies) are superior to other possible contexts in terms of the knowledge they produce? Later pragmatists including Hilary Putnam, Cheryl Misak, and Richard Rorty have quarreled over whether pragmatist epistemology implies a particular political stance or not (see Westbrook 2006 for review), but it is very clear that Mead saw a necessary connection between democratic inclusiveness and "smarter" political and social decision-making (Joas 1985: Ch. 9; Carreira da Silva 2008). Westbrook (2016) has recently argued that Mead's (1923) "Scientific Method and the Moral Sciences" gives a better "epistemological justification for democracy" than even his friend and colleague, John Dewey, was able to mount. In Mead's view, as in Max Weber's (1946), modern scientific inquiry cannot determine the ends toward which social reconstruction should be directed, but such inquiry can formulate those ends more systematically by virtue of its capacity to estimate the consequences of various pursuits. Mead takes this insight in a novel direction by arguing that democracy is a necessary condition of scientific inquiry, because good science welcomes all interested inquirers to its deliberations. Thus, a society that hopes to deploy the best scientific inquiry on behalf of its social reconstruction - what we might want to call better knowledge - would thus have to have political institutions that seek to allow any values and interests a seat at the table. Social inquiry, in order to be as successful as possible, must be as inclusive as possible, but we are always faced with pressing demands to solve the problems at hand that cannot await the realization of full democratic participation. So there is a continual tension between the practices of democracy in the present and the ideals of full democratic deliberation that would provide the most effective knowledge in the service of social reconstruction - a dynamic in which democratic reform and social inquiry are intertwined and mutually reinforcing. There is, in Mead's work, a sense that the work to bring people to the table and to view oneself from the perspective of others is always ongoing and practically accomplished wherever people engage in cooperative social processes.

In a recent work, Jean-François Côté (2015) argues that Mead took this line of argument even further by providing a theory of society as a dynamic, self-grounding totality. Drawing especially from Mead's work on political rights and internationalism (Mead 1915a, 1915b; 1929b, 1936: Ch. XVI), he proposes that Mead sketched the historical evolution of a form of society capable of being permanently self-conscious, not in the sense that it becomes a metaphysical entity nor that it solves all social problems, but rather one in which social action as a whole could be guided by continual anticipations of practical consequences from participants in democratic politics. In this way, science and democracy are again necessarily intertwined. The key, according to Côtés reading, may be found in the way that democratic societies institutionalize an engine of social selftransformation into their political constitution. In Mead's (1915a: 141-2) words, the 
creation of representative democracy, itself, involves an "institutionalizing of revolution" so that instead of permanently securing a fixed structure of government they secure "the opportunity for continual change." This, of course, does not mean that we should take Mead to naively believe in the irreversible progress of democracies. As Joas $(1985,2016$; see also Deegan 2011) has argued, such faith was shattered, if for no other reason, by World War I.

Related to this claim that better knowledge may be grounded in more democratic social practices, and in part explaining the mechanism by which this process may take place, is Mead's "semiotic" or communicative theory of human action, with its notion of universal role-taking. Joas $(2016,2013)$, especially, has been concerned with the problem of historicism and has worked to develop a synthesis of pragmatism and Ernst Troeltsch's "existential historicism" that is adequate to address such problems. ${ }^{6}$ Mead's theory of action is not capable of providing a final "absolute" or "ideal" end to historical inquiry, but it may suggest a unique criterion for validity claims while still acknowledging the radically temporal or historical nature of all human experience and, consequently, of all human ideals. In Mead's view, symbols extend far beyond their emergence and use in particular social interactions (as they were implicitly understood in much "Symbolic Interactionist" sociology that claims to descend from Mead), because symbolic acts bear a reference to a "universe of discourse" - a continually emerging social totality defined by all those individuals who can understand the symbol in functionally identical terms and for whom the symbol can become a reference point for action. Now, Herbert Blumer's (1969: 20, 60) classic statement of the theory and method of "Symbolic Interactionism" does acknowledge the historicity of each new social situation by arguing that any instance of "joint action" necessarily "emerges out of and is connected with a context of previous joint action" and "cannot be understood apart from that context" or "historical linkage." However, much of Blumer's work lacks a sense of anything fundamentally new emerging in social life - new situations, new institutions, and new actions, surely emerge in his view, but out of other situations, institutions, and actions - leading to a rather flattened view of historical development. It is difficult in such work to find a theoretical ground for the emergence of "international mindedness" out of national mindedness, of a society capable of intelligent self-regulation out of a habitually-oriented society, or of human consciousness emerging through historical social process, all problems that concerned Mead's more dynamic, emergent view of historical change. And in this regard, mainstream sociological approaches to history by way of the study of sequences of interactions or the development of institutions fare little better. Still, Blumer was closest to recovering Mead's view when he reflected on the rise of industrialization, social movements, and scientific discoveries (esp. Blumer 1990; see also Blumer 1969: 23, 47).

Mead's semiotic approach to action allows for the emergence of multiple and overlapping universes of discourse and for collective symbolic actions, such as the acts of a social institution. Take, as Côté (2015: 123) suggests, the example of the conferral of rights upon some individual or group: such a performative act becomes a reference point for other institutions and actors in other contexts, even those who would oppose them. Indeed, as Mead (2015: 161-2, 199, 261, 267-8; 1936: 13-9, 21, 25-7) repeatedly argued, a right to "property" is more than just "possession" precisely because of its symbolic character anyone who would claim it as a right must also recognize that claim as reciprocal when made by others. This symbolic character of human action also allows it to transcend the ongoing present (while still being rooted therein) in order to reflect on the past and to 
anticipate the future (Mead 2015: 350). And Mead (2015: 202-3, 281-9; 1929b) sought to show how, when new relationships form that expand the social processes in which people participate, symbolic communication becomes more universal in its reference, and that fundamental changes in the nature of these symbolic referents characterize the transitions from one historical period to another.

In this view, the social importance of historical inquiry lies in the historian's ability to trace out the developments - social "changes, forces and interests" - that were not present in the conscious experience of the members of the community at the time (Mead 2015: 256). The life of the whole social process in which the individual is involved transcends the experience of the individual, and Mead argues that it is precisely the vital work of historians to bring more of that process into focus. The unique vantage point of the historian does not come merely from the abstract passage of time, but from processes of "social reconstruction" that allow people to identify with one another in ways that they had not previously (Mead 2015: 297). Human diversity is, thus, productive of social progress when people who had not previously been brought in contact are incorporated into cooperative acts together. ${ }^{7}$ Because such practical forms of social participation lead people to become more self-conscious of the broader community life of which they are a part, inclusive social processes also make for a more universal standpoint from which to evaluate past events.

of course, everything still remains to be done in order to turn this suggestion into a practical guide for history. The specific paths by which inclusive social processes would make for better knowledge, how we can determine what counts as "more inclusive" arrangements in a practical sense, the origins of the human diversity that drives changes in social perspectives, and other problems all remain open questions and lead us back into ongoing debates in contemporary ethics, politics, and philosophy. Nevertheless, connecting the lines of argumentation sketched in this section leads us to the suggestive possibility that there is a ground for better historical knowledge in such a democratically inclusive and self-transformative social order, because in rewriting history from the standpoint of a more inclusive social process we find a claim to greater universality. This approach preserves an understanding of the historicity of our knowledge about history (as well as about other topics) while also suggesting how social change can be more or less conducive to progress in our historical knowledge.

\section{The Historian's Social Responsibility}

Perhaps one of the most unique contributions Mead can make to historical research and thought, a contribution that helps bring together the practical implications of Mead's approach, is his notion of responsibility. In an early review essay, Mead (1897: 790) already called responsibility "the most central of all the expressions of personality." In the view of Mead's social philosophy, the personality is always developing through social processes that change and enlarge our self-consciousness, and one of the key functions of that self-consciousness is anticipatory control over one's own responses to a situation. This makes us responsible not only for our own conduct, but also for shaping the changes in other individuals' conduct involved in the same cooperative action (Mead 2015: 403). Thus, there is an imperative sense in which to become a more fully conscious personality or self is to accept the responsibility both to know one's own attitudes and habits and to 
display or represent the action in which one is involved in a conscientious way that will lead to successful cooperative processes, however success is situationally defined.

From nearly the earliest reflections on his understanding of history, Mead's students and colleagues made the case that his historical work was necessarily intertwined and inextricable from his more well-known theory of the self (Moore 1936: xxvii-xxxvi; and Murphy 1936), but this observation has rarely been developed. For the historian, Mead's approach means a self-conscious recognition of the collective and ongoing enterprise of historical inquiry in which people are involved together, as well as a socially-rooted responsibility to conduct that inquiry conscientiously. Mead (2015: 175-8, 182-3, 203) emphasized that, regardless of whether someone takes a stand in criticism or in support of some particular situation, that response involves an acceptance of responsibility for the situation. Taken seriously, this responsibility may lead us to conclude that the conscientious approach to history is to conduct ourselves in such a way that we can both locate our claims historically and take responsibility for the subsequent consequences of our claims about historical events. If we accept Mead's approach to the problem of "presentism," we may conclude that conscientious historical inquiry means both crafting claims that are open to - and expect - revision by the ongoing process of historical discovery (Huebner 2014: 218-20) and seeking out precisely the evidence and the social perspectives that would provoke those revisions. Only if one truly accepts Mead's radical conclusion - that the history to which we look back, itself, changes as society changes, and not that history is unaffected by our changing social perspectives on it - does the full weight of the historian's responsibility really become apparent. The possibilities of historical investigation only develop in the course of history, not in the abstract, Idealist sense of Mind's self-unfolding, but in the sense of practical social developments providing new perspectives on events, and hence a responsibility to shape those developments. And if we accept the further connections sketched between knowledge and democratic politics, we may further conclude that historical knowledge is better whenever it can be shown to refer to - and be the result of - more inclusive social processes.

\section{BIBLIOGRAPHY}

Аввотт Andrew, (2001), Time Matters: On Theory and Method, Chicago, University of Chicago Press. ADAMS Julia, CLEMENS Elisabeth S., \& Ann Shola ORLOFF, (2005), "Introduction: Social Theory, Modernity, and the Three Waves of Historical Sociology," in Remaking Modernity: Politics, History, and Sociology, Durham, NC, Duke University Press.

ANSELL Christopher, (2011), Pragmatist Democracy: Evolutionary Learning as Public Philosophy, New York, Oxford University Press.

BAERT Patrick, (2005), "Towards a Pragmatist-Inspired Philosophy of Social Science," Acta Sociologica, 48, 3, 191-203.

BALDWIN John D., (1988), "The Matter of Habit and G. H. Mead: Comment on Camic," American Journal of Sociology, 93, 4, 952-7. 
BAUMGARTEN Eduard, (1936), “John Dewey I: Die Idee der Demokratie," Internationale Zeitschrift für Erziehung, 5, 81-96.

Baumgarten Eduard, (1938), Der Pragmatismus: R. W. Emerson, W. James, J. Dewey, Vol. II, Frankfurt a. M., V. Klostermann.

BECKER Howard, (1976), Sociological Work: Method and Substance, New Brunswick, NJ, Transaction Publishers.

BERGMANN Werner, (1981), “Zeit, Handlung und Sozialität bei G. H. Mead,” Zeitschrift für Soziologie, $10,4,351-63$.

BLUMER Herbert, (1969), Symbolic Interactionism: Perspective and Method, Englewood Cliffs, NJ, Prentice Hall.

BLUMER Herbert, (1990), Industrialization as an Agent of Social Change: A Critical Analysis, edited by David R. Maines \& Thomas J. Morrione, New York, Aldine de Gruyter.

BoURgeols Patrick, \& Sandra B. Rosenthal, (1990), "Scientific Time and the Temporal Sense of Human Existence: Merleau-Ponty and Mead," Research in Phenomenology, 20, 1, 152-63.

BOURGEoIs Patrick, \& Sandra B. Rosenthal, (1993), “The Present as the Seat of Temporal Existence: Merleau-Ponty and Mead," International Studies in Philosophy, 25 (3), 1-15.

BROGAARD Berit O., (1999), "Mead's Temporal Realism," Transactions of the Charles S. Peirce Society, $35,3,563-93$.

CAMIC Charles, (2016), “Changing 'Movements of Thought in the Nineteenth Century': Historical Text and Historical Context," in The Timeliness of George Herbert Mead, edited by Hans Joas \& Daniel R. Huebner, Chicago, University of Chicago Press.

CAMPBELl James, (2013), “Mead's Understanding of Movements of Thought," in George Herbert Mead in the Twenty-first Century, edited by F. Thomas Burke \& Krzysztof Skowronski, Lanham, MD, Lexington Books.

CARREIRA DA SILVA Filipe, (2008), Mead and Modernity: Science, Selfhood, and Democratic Politics, Lanham, MD, Lexington Books.

CASTELL Alburey, (1937), "[Review] Movements of Thought in the Nineteenth Century, by George H. Mead," Journal of Modern History, 9, 1, 86-8.

CHILD Arthur, (1941), “The Problem of Imputation in the Sociology of Knowledge," Ethics, 51, 2, 200-19.

Collingwood R. G., (1956), The Idea of History, New York, Oxford University Press.

COLLINGWOoD R. G., (1999), The Principles of History and Other Writings in Philosophy of History, edited by W.H. Gray \& W.J.van der Dussen, Oxford, Oxford University Press.

CоoK Gary A., (1979), “Whitehead's Influence on the Thought of G. H. Mead," Transactions of the Charles S. Peirce Society, 15, 2, 107-31.

COOK Gary A., (1992), “George Herbert Mead: An Unpublished Essay on Royce and James,” Transactions of the Charles S. Peirce Society, 28, 3, 583-92.

CôTÉ Jean-François, (2013), “George Herbert Mead on Ancient Greek Society: An Introduction,” Canadian Journal of Sociology, 38, 3, 383-405.

CÔTÉ Jean-François, (2015), George Herbert Mead's Concept of Society: A Critical Reconstruction, Boulder, CO, Paradigm Publishers. 
DEEGAN Mary Jo, (2011), Self, War, and Society: George Herbert Mead's Macrosociology, New Brunswick, NJ, Transaction Publishers.

DEWEY John, (1997), The Correspondence of John Dewey, 3 Vols., edited by Larry Hickman, Charlottesville, VA, InteLex Past Masters.

DRAKE Durant, LOVEJOY Arthur O., PRATT James B., ROGERS Arthur K., SANTAYANA George, SELLARS Roy Wood, \& C. A. STRONG, (1920), Essays in Critical Realism: A Co-operative Study of the Problem of Knowledge, London, Macmillan and Co.

DURKHeIM Émile, (1983 [1913/14]), Pragmatism and Sociology, translated by J. C. Whitehouse, edited by John B. Allcock, Cambridge, Cambridge University Press.

EAMES Elizabeth R., (1973), "Mead's Concept of Time," in The Philosophy of G. H. Mead, edited by W. R. Corti, Winterthur, Switzerland, Amriswiler Bücherei.

EFFELBERGER Hans, (1936), “Die Gegenwartsbedeutung der amerikanischen Philosophie,” Die neueren Sprachen 44, 487-96.

FEN Sing-Nan, (1951), "Present and Re-Presentation: A Discussion of Mead's Philosophy of the Present," Philosophical Review, 60, 545-50.

FlAHERTY Michael G., \& Gary Alan FINE, (2001), "Present, Past, and Future: Conjugating George Herbert Mead's Perspective on Time," Time and Society, 10, 147-61.

FRINGS Manfred S., (1983), “Social Temporality in George Herbert Mead and Scheler," Philosophy Today, 27, 281-9.

GARCIA RUIZ Alicia, (2013), “The Concept of the Present and Historical Experience," in George Herbert Mead in the Twenty-first Century, edited by F. Thomas Burke \& Krzysztof Skowronski, Lanham, MD, Lexington Books.

GEHLEN Arnold, (1951), “Der Gegenwärtige Stand der anthropologischen Forschung," Merkur: deutsche Zeitschrift für europäisches Denken, 38, 379-89.

GRoss Neil, (2009), “A Pragmatist Theory of Social Mechanisms," American Sociological Review, 74, 3 , 358-79.

Gross Neil, (2010), "Charles Tilly and American Pragmatism," The American Sociologist, 41, 4, 337-57.

HERMAN Thelma, (1944), "Pragmatism: A Study in Middle-Class Ideology," Social Forces, 22, 4, 405-10.

HOLT B. Edwin, MARVIN Walter T., MONTAGUE W. P., PERRY Ralph B., PITKIN. Walter B, \& E. G. SPAULDING, (1912), The New Realism: Cooperative Studies in Philosophy, New York, Macmillan. HUEBNER Daniel R., (2013), "Wilhelm Jerusalem's Sociology of Knowledge in the Dialogue of Ideas," Journal of Classical Sociology, 13, 4, 430-59.

HUEBNER Daniel R., (2014), Becoming Mead: The Social Process of Academic Knowledge, Chicago, University of Chicago Press.

HUEBNER Daniel R., (2016), “On Mead's Long Lost History of Science,” in The Timeliness of George Herbert Mead, edited by Hans Joas \& Daniel R. Huebner, Chicago, University of Chicago Press. JERUSAlEM Wilhelm, (1909), “Die Aufgabe der Soziologie," Monatsschrift für Soziologie, 1, 7, 550-8. JOAS Hans, (1985), G. H. Mead: A Contemporary Re-examination of His Thought, 2nd rev. ed. 1997, translated by Raymond Meyer, Cambridge, MA, MIT Press. 
JOAS Hans, (1993), Pragmatism and Social Theory, Chicago, University of Chicago Press.

JOAS Hans, (1996), The Creativity of Action, Chicago, University of Chicago Press.

JOAS Hans, (2013), The Sacredness of the Person: A New Genealogy of Human Rights, Washington, DC, Georgetown University Press.

JOAS Hans, (2016), "Pragmatism and Historicism: Mead's Philosophy of Temporality and the Logic of Historiography," in The Timeliness of George Herbert Mead, edited by Hans Joas \& Daniel R. Huebner, Chicago, University of Chicago Press.

JOAS Hans, \& Daniel R. HUEBnER, (eds.), (2016), The Timeliness of George Herbert Mead, Chicago, University of Chicago Press.

LEAHY Daniel J., (1953), “A Pragmatic Theory of Past, Present and Future," Review of Metaphysics, 6, 3, 369-80.

LEE Harold N., (1963), “Mead's Doctrine of the Past," Tulane Studies in Philosophy, 12, 52-75.

LOVEJoY Arthur O., (1939), "Present Standpoints and Past History," Journal of Philosophy, 36, 18, 477-89.

MAINES David R., (1993), "Narrative's Moment and Sociology's Phenomena: Toward a Narrative Sociology," Sociological Quarterly, 34, 1, 17-38.

MAINES David R, SUGRUE Noreen M., \& Michael A. KATOVich, (1983), “The Sociological Import of G. H. Mead's Theory of the Past," American Sociological Review, 48, 2, 161-73.

MANDELBAum Maurice, (1948), "Arthur O. Lovejoy and the Theory of Historiography," Journal of the History of Ideas, 9, 4, 412-23.

MANNHEIM Karl, (1936 [1929]), Ideology and Utopia: An Introduction to the Sociology of Knowledge, translated by Louis Wirth \& Edward A. Shils, New York, Harcourt Brace.

MARGOLIS Joseph, (1986), Pragmatism Without Foundations: Reconciling Realism and Relativism, Oxford, Basil Blackwell.

MARGoLIS Joseph, (2002), Reinventing Pragmatism: American Philosophy at the End of the Twentieth Century, Ithaca, NY, Cornell University Press.

MARGoLIS Joseph, (2006), "Pluralism, Relativism, and Historicism," in A Companion to Pragmatism, edited by John R. Shook \& Joseph Margolis, Malden, MA, Blackwell Publishing.

MEAD George H., (1896), “Some Aspects of Greek Philosophy," University of Chicago Record 1, 42.

MEAD George H., (1897), “[Review] Untersuchungen zur Phänomenologie und Ontologie des Menschlichen Geistes by Dr. G. Class," American Journal of Theology 1, 789-92.

MEAD George H., (1899), “The Working Hypothesis in Social Reform,” American Journal of Sociology 5, 404-12.

MEAD George H., (1908), “The Philosophical Basis of Ethics,” International Journal of Ethics 18, 311-23.

MEAD George H., (1910), "Untitled response to a paper by Professor Robinson," in Box 14, Folder 1, George Herbert Mead Papers, 1883-1964, Special Collections Research Center, Joseph P.

Regenstein Library, University of Chicago.

MEAD George H., (1915a), "Natural Rights and the Theory of the Political Institution," Journal of Philosophy 12, 141-55. 
MEAD George H., (1915b), “The Psychological Bases of Internationalism,” Survey 33, 604-7.

MEAD George H., (1917a), "Scientific Method and Individual Thinker," in Creative Intelligence: Essays in the Pragmatic Attitude, edited by John Dewey et al., New York, Henry Holt and Co.

MEAD George H., (1917b), “Josiah Royce - A Personal Impression,” International Journal of Ethics 27, 168-70.

MEAD George H., (1923), "Scientific Method and the Moral Sciences," International Journal and Ethics $23,229-47$.

MEAD George H., (1929a), "The Nature of the Past," in Essays in Honor of John Dewey, edited by John Coss, New York, Henry Holt.

MEAD George H., (1929b), "National-Mindedness and International-Mindedness," International Journal of Ethics 39, 385-407.

MEAD George H., (1929c), “A Pragmatic Theory of Truth," University of California Publications in Philosophy 11, 65-88.

MEAD George H., (1930), "The Philosophies of Royce, James, and Dewey in Their American Setting," International Journal of Ethics 40, 211-31.

MEAD George H., (1932), The Philosophy of the Present, edited by Arthur E. Murphy, Chicago, Open Court.

MEAD George H., (1935), “The Philosophy of John Dewey,” International Journal of Ethics 46, 64-81.

MEAD George H., (1936), Movements of Thought in the Nineteenth Century, edited by Merritt H. Moore, Chicago, University of Chicago Press.

MEAD George H., (1938), The Philosophy of the Act, edited by Charles W. Morris, John M. Brewster, Albert M. Dunham, and David L. Miller, Chicago, University of Chicago Press.

MEAD George H., (2015 [1934]), Mind, Self, and Society: The Definitive Edition, revised edition edited by Daniel R. Huebner and Hans Joas, original edition by Charles W. Morris, Chicago, University of Chicago Press.

MILler David L., (1943), “G. H. Mead's Conception of the Present,” Philosophy of Science 10, 40-6.

MILLER David L., (1973), George Herbert Mead: Self, Language, and the World, Austin, TX, University of Texas Press.

MILLS Wright C., (1966), Sociology and Pragmatism: The Higher Learning in America, New York, Oxford University Press.

MINK Louis O., (1969), Mind, History, and Dialectic: The Philosophy of R. G. Collingwood, Bloomington, Indiana University Press.

MOORE Merritt H., (1936), "Introduction," in Movements of Thought in the Nineteenth Century, by George H. Mead, Chicago, University of Chicago Press.

MURPHY Arthur E., (1932), "Introduction," in The Philosophy of the Present, by G. H. Mead, Chicago, Open Court.

MURPHY Arthur E., (1936), "[Review] Movements of Thought in the Nineteenth Century, by G. H. Mead," Journal of Philosophy, 33, 14, 384-6.

NATANSON Maurice, (1953), “George H. Mead's Metaphysics of Time,” Journal of Philosophy, 50, 25, 770-82. 
NEF CASTLE Elinor, (1953), Letters \& Notes, Los Angeles, Ward Ritchie Press.

NowotnY Helga, (1992), "Time and Social Theory: Towards a Social Theory of Time," Time and Society $1,421-54$.

O’TOoLE James M., \& Richard J. cox, (2006), Understanding Archives \& Manuscripts, Chicago, Society of American Archivist.

PARSONS Talcott, (1937), The Structure of Social Action: A Study in Social Theory with Special Reference to a Group of Recent European Writers, New York, McGraw Hill.

POWELL Walter W., \& Paul DIMAGGIO, (1991), The New Institutionalism in Organizational Analysis, Chicago, University of Chicago Press.

RIGNEY Ernest G., \& Timothy C. LUNDY, (2015), “From a Pragmatist's Point of View: George Herbert Mead's Unattributed Review of Theodore Merz's A History of European Thought in the Nineteenth Century," European Journal of Pragmatism and American Philosophy, 7, 1, 191-203. SCHELER Max, (1926), Die Wissensformen und die Gesellschaft, Leipzig, Der Neue-geist Verlag. SCHNEIDERHAN Erik, (2011), "Pragmatism and Empirical Sociology: The Case of Jane Addams and Hull-House, 1889-1895," Theory and Society, 40, 6, 589-617.

sсотт Richard W., (1995), Institutions and Organizations, Thousand Oaks, CA, Sage Publications. STONE Jake E., (2013), “Mead's Interpretation of Relativity Theory," Journal of Speculative Philosophy , 27, 2, 153-71.

STRAUSS Anselm, (1991), "Mead's Multiple Conceptions of Time and Evolution: Their Contexts and Their Consequences for Theory," International Sociology, 6, 4, 411-26.

THOMAs Michael L., (2016), "Mead, Whitehead, and the Sociality of Nature," in The Timeliness of George Herbert Mead, edited by Hans Joas \& Daniel R. Huebner, Chicago, University of Chicago Press.

TILLMAN Mary Katherine, (1970), "Temporality and Role-Taking in G. H. Mead," Social Research, 37, $4,533-46$.

TONNESS Alfred, (1933), “A Notation on the Problem of the Past - with Especial Reference to George Herbert Head," Journal of Philosophy, 29, 22, 599-606.

USHENKo Andrew, (1934), “Discussion: Alternative Perspectives and the Invariant Space-Time," Mind, 43, 170, 199-203.

VAN DER DUSSEN Jan, (2015), Studies on Collingwood, History and Civilization, New York, Springer. WAGNER-PACIFICI Robin, (2010), "Theorizing the Restlessness of Events," American Journal of Sociology, 115, 5, 1351-86.

WEBER Max, (1946 [1917]), "Science as a Vocation," in From Max Weber: Essays in Sociology, edited by Hans H. Gerth \& C. Wright Mills, New York, Oxford University Press.

WEST Cornel, (1989), The American Evasion of Philosophy: A Genealogy of Pragmatism, Madison, WI, University of Wisconsin Press.

WESTBROOK Robert, (2006), "Liberal Democracy," in A Companion to Pragmatism, edited by John R. Shook \& Joseph Margolis, Malden, MA, Blackwell Publishing. 
WESTBROOK Robert, (2016), “George Herbert Mead and the Promise of Pragmatist Democracy," in The Timeliness of George Herbert Mead, edited by Hans Joas and Daniel R. Huebner, Chicago, University of Chicago Press.

WiLliams Donald C., (1934), “The Argument for Realism,” The Monist, 44, 2, 186-209.

\section{NOTES}

1. In the confines of this paper I am unable to fully articulate the possible tensions between two views of the core of pragmatism: as either a theory of action or a theory of truth or knowledge (let alone other possible interpretations). These views are obviously complementary in many respects, and the particular emphasis on one or the other depends largely on what use can be made of the label "pragmatist" in different contexts. With regard to the classical pragmatists, it may be worth noting that a clear articulation of pragmatism as a theory of action dates at least as far back as Wilhelm Jerusalem's (1909: 554-5) work to develop a "sociology of knowledge" [ Erkennen] in which he claimed that pragmatism was ultimately a theory of "the intimate interrelation between theoretical thought and human organization invested in its very core with activity, with action." Of course, the classical American pragmatists, themselves, made this argument (perhaps especially in the work of John Dewey from the 1890s onward), but Jerusalem is perhaps the first scholar who, upon encountering the work of American pragmatism, developed its theory further along the lines of a theory of action. Although many early critics also focused on pragmatism as a theory of knowledge or truth, some others who appear to have been influenced by Jerusalem's reading, such as Émile Durkheim (1983 [1913-14]) and Max Scheler (1926), focused instead on its approach to action (cf. Huebner 2013). In Durkheim's (1983: chaps. 13,16) view, in particular, the ability to explain historical events is a critical test for a coherent philosophy, and pragmatism's apparent individualistic starting-point (he was thinking mostly of James) failed to provide an account of historical action that was as adequate as his own sociological theory.

2. Collingwood (1956) is, of course, known for his thesis that all history is the history of thought, because in his view what interests historians in human actions is the rationality they express. Although this approach is avowedly idealist, recent scholarship has sought to free Collingwood of the charge that he over-rationalized the object of history by showing his expansive approach to the nature of what counts as "reason" in action (van der Dussen 2015). Louis Mink (1969) was among the earliest and most explicit in attempting to draw connections between pragmatist and Collingwoodian philosophies of history; and we might add that Collingwood's ideas - that historical knowledge is the "reenactment" of historical events in the mind of the historian and that ultimately the purpose of historical inquiry is general "human self-knowledge" - present interesting connections that could be further developed between the two philosophies. Of course, Collingwood is by no means the only theorist to conclude that history is essentially the study of action, and it is interesting to note that even the practical literature on the management of archives draws the same conclusions to support an understanding of how archival materials may serve as documents of human social life (e.g., O'Toole \& Cox 2006: 87-92).

3. It may also be noted that the very process of inquiry in which the individual's experience is central to advancing knowledge of reality is, itself, the result of the individual becoming a historical problem for society, according to Mead. This is a topic Mead apparently discussed in his lectures, both with reference to how the individual emerged as a problem for social consciousness in the development of modern nations and citizenship and with reference to psychological and ethical theories, which were faced by problems of social control. For additional discussion, see Huebner (2016: 44-5). 
4. In his posthumously published manuscript on "The Philosophy of John Dewey" (Mead 1935), which was likely originally a preparatory essay for his talk on the occasion of John Dewey's 70th birthday (Mead 1930), Mead discussed American philosophy in light of historian Frederick Jackson Turner's "most illuminating conception," the so-called frontier thesis, arguing that pioneer settlers were forced by circumstances to justify their institutions by their usefulness and the ability to serve more than one purpose rather than subjecting them to purely philosophical criticism. These articles also have two more autobiographical counterparts in which Mead locates his own intellectual development in these same social contexts (see Mead 1917b; Cook 1992).

5. Eduard Baumgarten, who was a nephew of Max Weber, studied and lectured in the United States at Columbia University, the University of Chicago, and the University of WisconsinMadison, and had definitely met both Dewey and Mead in the late 1920s before returning to Germany. He even apparently discussed with Mead the possibility of translating Dewey's Experience and Nature into German (M. C. Otto to J. Dewey, 19 December 1928; Dewey [1997], no. 05085). Joas (1993: 110) has pointed out that Baumgarten was the "decisive figure," the "catalyst," in "conveying the ideas of pragmatism to fascist intellectuals," including Arnold Gehlen and Helmut Schelsky, in pre-World War II Germany. One can underscore this point by noting that a few of these scholars referred to Mead's "Royce, James, and Dewey" essay explicitly on the basis of Baumgarten's analysis (e.g., Effelberger 1936; Gehlen 1951). It appears that these fascist theorists drew upon what Mead took to be an ethically positive claim - that pragmatist philosophy was linked with particular American democratic practices - to criticize its general philosophic importance and perhaps also to attempt to ground fascist theories of action.

6. Joas (2016) seems to argue that Mead's "semiotic anthropology" is the correct direction for historical knowledge, but finds that on several accounts Mead does not ultimately provide all the tools necessary for this endeavor - for which we must look especially to ideas from Ernst Troeltsch and Josiah Royce. In particular, Mead does not ground the conditions for our ethos of universalism, itself (i.e., why we find a moral necessity in seeking universal cognitive or ethical claims), he does not provide a fully elaborated theory of narration as key to the historical research process, and he seems not to make an explicit and dedicated attempt to connect his theory of universal role-taking with the development of ideals as a way of addressing his radical temporality. Joseph Margolis $(2006 ; 1986)$ is another major voice to have attempted to work out such a synthesis between pragmatism and historicism. Although Margolis (2002: 131) acknowledges that Mead's historical investigations have been "almost entirely neglected," even by John Dewey, he does not give any substantive discussion to Mead's ideas and underestimates the breadth and depth of Mead's historical work, which he characterizes as "very limited."

7. Historically important forms of this integration, according to Mead (2015: chaps. 36-7), have included incorporation in economic trade and production relationships and in universalistic religions, although Mead was very aware of the need to differentiate between exploitative and cooperative economic and religious arrangements.

\section{ABSTRACTS}

Although not known as a philosopher of history, George Herbert Mead wrote and taught seriously about the nature of the past and about historical investigation throughout his career. The paper identifies the major documentary sources and interpretive literature with which to 
reconstruct Mead's radically social and dynamic conceptualization of history and extends beyond the existing literature to develop striking implications of Mead's approach in response to possible criticisms and challenges. By connecting Mead's writings on history with his broader social theory of action, democracy, and consciousness, the paper shows how Mead provides a novel grounding of our understandings of history in ongoing social processes and suggests that better historical knowledge may be related to participatory, inclusive social practices. As a result, historians have a responsibility to social reconstruction and society's self-reflection, in Mead's view. Because of the novel ways in which Mead's approach explores the relationship between history and social progress he warrants renewed attention and scrutiny from researchers and theorists of history.

\section{AUTHOR}

\section{DANIEL R. HUEBNER}

University of North Carolina at Greensboro

drhuebne[at]uncg.edu 